\title{
Julian T. (Buz) Hoff Obituary
}

KARIN MuRaszKo, M.D.

Julian T. Hoff Professor and Chair, Department of Neurosurgery, University of Michigan

$\mathrm{J}$

ULIAN THEODORE ("Buz") HofF, M.D., passed away on April 16, 2007. After a 7-month battle with acute leukemia, he died peacefully at home with the comfort of his loving family. Although his life seemed to be cut short, his was a life well-lived and he will be missed.

Dr. Hoff was born September 22, 1936, to Harvey O. and Helen B. Hoff in Boise, Idaho. He spent his childhood years in Caldwell, Idaho, where he worked at his father's lumberyard, playing baseball, and mastering the piano. In Boy Scouts, he achieved the rank of Life Scout. As a senior, he was elected student body president of Caldwell High School.

In 1954, he entered as a freshman to Stanford University, where he received a baseball scholarship. He was accepted to medical school in 1958 at New York Hospital Cornell Medical School. During his first summer after medical school, he met his future bride-Diane Shanks, a nurse at Sequoia Hospital in Redwood City, California. They were married in Bellport, Long Island, New York, on June 3, 1962.

After completing 2 years of general surgery training, he served as a Captain in the US Army Medical Corps in Japan. In 1966, he began neurosurgery training under the mentorship of Dr. Bronsen Ray at New York Hospital, and during this time, he developed his life-long interest in the science of brain edema and stroke.

Recognized as a rising star, Buz was recruited to University of California San Francisco by Dr. Charles Wilson. The Hoff family then moved west. The next 11 years in San Francisco were the formative ones of his academic career, and he was advanced to the level of full professor in 1978. Numerous scholarly publications, a National Institutes of Health $(\mathrm{NIH})$ grant, and numerous teaching awards contributed to his growing legend as a "triple threat" - teacher, scientist, and physician.

In 1981, Michigan once again beat California when they recruited Buz Hoff to chair the section of neurosurgery. Through his leadership, the division grew from a small, solid core of four full-time faculty members to a department comprising 18 clinical faculty and a fully supported laboratory with more than 25 scientists investigating the causes and treatment of brain edema and stroke. The department is now recognized as one of the premier neurosurgery training programs in the country. During his 25 years as chairman, he trained nearly 50 neurosurgeons.

Buz had a distinguished career in neurosurgery, serving

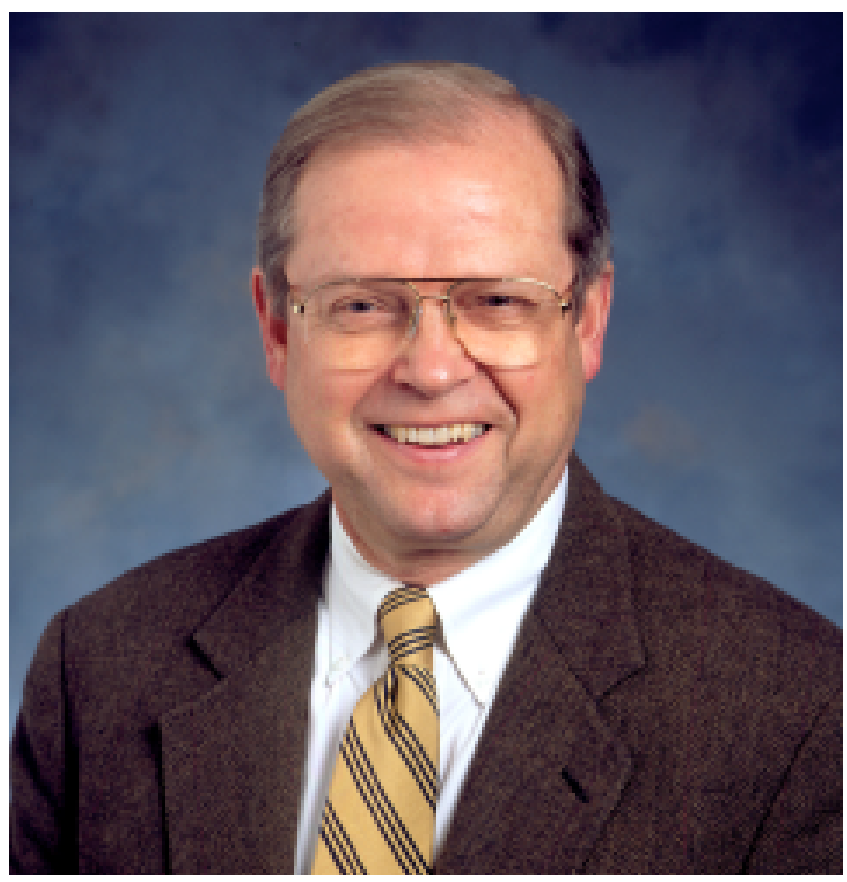

on the editorial board of major neurosurgical journals and acting as cochair of the editorial board for the Journal of Neurosurgery from 1997 to 1999 . He maintained continuous NIH funding from 1972 until the present day. His most recent RO1 focused on mechanisms of brain edema after intracerebral hemorrhage. He received the prestigious Jacob Javits Award for Neuroscience Research twice (1985 and 1992) and was a member of the Institute of Medicine National Academy of Science since 1999. He received the Cushing Medal from the American Association of Neurological Surgeons (AANS) in 1990, the Grass Prize from the Society of Neurological Surgeons in 2001, was the honored guest of the Congress of Neurological Surgeons (CNS), and received the Distinguished Alumni Award from Caldwell High School in Caldwell, Idaho. He was an Honorary Member of the Society of British Neurological Surgeons. He was recently informed that he had received the Distinguished Service Award from the Society of Neurological Surgeons. He was the author of more than 200 scientific papers and 75 book chapters, in addition to being the editor of more than a dozen books. 
Buz served in executive positions in every major neurosurgical society, including President of the AANS and Vice President of the CNS. He was a member of the RRC for neurosurgery from 1987 to 1993 and had served on the appeals panel for neurosurgery since 1993 . Within the University of Michigan he worked on a variety of committees; whenever a complex job needed to be done, Buz was selected either by organized neurosurgery or the University of Michigan to perform that job, and he did so with wisdom and affability. Buz retired from clinical neurosurgery in 2006. He enjoyed redirecting his energy and interest in the Rotary Club and the First Presbyterian Church, where he served as a Deacon.

An Eagle Scout in his early life, Buz had been particularly beloved for his strong leadership abilities, which were displayed in a collegial and kind fashion. He became a respected leader and always remained a true gentleman. A strong advocate of resident education, he sought to create a collegial environment in which even the most complex political and scientific issues could be discussed with warmth and openness.

Dr. Hoff was particularly pleased that in 2006 the Michigan Department of Neurosurgery created an endowed chair honoring him. I have the priviledge of serving as the first Julian T. Hoff Professor of Neurosurgery and Chair of the Department of Neurosurgery. The department has also established a Resident Education and Research Fund in Dr. Hoff's name to continue his outstanding legacy of leadership in academic neurosurgery and his longstanding support of resident education.

A MONG THE THINGS that Buz valued most in his life were time with family and friends, teaching, and helping others. He was a lover of music, literature, art, sports, and travel. He was known for his wonderful gift of humor and for being a great storyteller. He always had time to listen. He was a humble, generous, fair, and kind man who was loved by many. His legacy is the impact on the many people he loved, helped, and taught throughout his life.

Dr. Julian Hoff is survived by his wife of 45 years, Diane (née Shanks) Hoff. He is also survived by three children, Paul Theodore Hoff, M.D. (Donna Hoff, M.D.), Allison Munro Hoff, M.A., and daughter Julia Anne (Michael) Haughey, M.S.W. He leaves five grandchildren, Lauren Louise Hoff, Kiersten Diane Hoff, Kathryn Munro Haughey, Kelly MacKay Haughey, and Charles Theodore Haughey. He is also survived by his brother Harvey Hoff, nephew Brian Hoff, niece Kristin (Hoff) Sinclair, and many loving cousins.

The family has asked that memorial contributions be sent to The Caldwell High School Julian T. Hoff Memorial Scholarship Fund in care of Kathy O'Banon, Caldwell Foundation for Educational Opportunity, 2311 Arlington Avenue, Caldwell, Idaho 83605, or to The Boy Scouts of America. 